\title{
11 So Close, Yet So Far: Ulrich Makosch and the GDR's Afrikabild on Screen and in Text
} Although our two states are located on different continents, Socialist Ethiopia is close and
dear to every citizen of our country.

Erich Honecker to Mengistu Haile Mariam, 1978. ${ }^{1}$

The GDR is often described as a "closed" society. ${ }^{2}$ This metaphor has a number of implications, mostly related to the very real restrictions placed on travel, goods, and exchange by the state. Indeed, travel restrictions have in many ways come to define it in both popular memory and the historiographical literature. In the order of the GDR's symbolic associations, the Berlin Wall remains primary, its figurative importance matched only by the vital practical role it played in perpetuating the state's existence. But were physical restrictions matched by similar limitations on ideas or images? Did state-produced media mirror the GDR's border regime, shielding citizens from the outside world? Or was such imagery and reportage used to make up for a lack of opportunity to travel? In a state where travel beyond the Eastern Bloc was difficult for most citizens, what role did reportage on the outside world play?

Thanks to a growing literature on the subject, we now know that international solidarity-particularly the variety practiced with non-European nations and

1 Stiftung Archiv der Parteien und Massenorganisationen der DDR im Bundesarchiv (hereafter SAPMO-BArch), DY 30/2419, “Toast während des Essens zu Ehren Mengistu Haile Mariams,” 1. 2 The GDR has frequently been depicted as deliberately resisting global forces; see, for example Charles S. Maier, Dissolution: The Crisis of Communism and the End of East Germany (Princeton: Princeton University Press, 1999), 104; Gareth Dale, Between State Capitalism and Globalisation: The Collapse of the East German Economy (Oxford: Peter Lang, 2004), 340; Olaf Klenke, Ist die DDR an der Globalisierung gescheitert? : Autarke Wirtschaftspolitik versus internationale Weltwirtschaft ; das Beispiel Mikroelektronik (Frankfurt am Main: Peter Lang, 2001), 111; Christoph Buchheim, "Die Achillesferse der DDR - der Aussenhandel," in Überholen ohne einzuholen : die DDRWirtschaft als Fußnote der deutschen Geschichte?, ed. André Steiner, Forschungen zur DDR-Gesellschaft (Berlin: Ch. Links, 2006), 91; Peter Grieder, The German Democratic Republic (Basingstoke: Palgrave Macmillan, 2012). No state in the world has ever been completely autarchic, of course. Some scholars have acknowledged that state-socialist countries traded with the rest of the world, although still argue for autarchy-or at least "near-autarchy"-on the basis that these states didn't take part in "outward-orientated developmental strategy" or "international specialization”. See for example Jan Winiecki, Shortcut or Piecemeal: Economic Development Strategies and Structural Change (Budapest: Central European University Press, 2016), 24.

Ә OpenAccess. (C) 2021 George Bodie, published by De Gruyter. (cc) BY This work is licensed under the Creative Commons Attribution 4.0 International License. https://doi.org/10.1515/9783110623543-011 
movements-played an important role in GDR culture, political discourse, and everyday life. For the most part, this culture of solidarity was rooted in imagery and iconography. As Quinn Slobodian has shown, "for the great majority of the East German population, icons and contributions rather than personal experience remained the means of engaging with the global South and activists of colour." 3 A number of scholars have explored the shape and form of this iconography. ${ }^{4}$ Very little work has been done on the content of foreign news reporting however, which was one of the most quotidian and widespread mediums through which this iconography was disseminated: an absence that is perhaps unsurprising given the Cold War consensus that news, to quote Simon Huxtable, "was alien to the communist world view." 5

The GDR's cultures of solidarity were not monodirectional, however: they also grew from the strategic concerns of national liberation movements in Africa. Socialist journalists from the Eastern Bloc sought to convey the image of a growing socialist world to their fellow citizens, but they were also used by national liberation movements and newly independent states to spread their own messages, creating transnational entanglement. In the throes of anti-colonial struggle or the early days of independence, such movements and states were often reliant upon foreign bureaus. ${ }^{6}$ As Matthew Connolly has shown in the case of the National Liberation Front (FLN) in Algeria, "human rights reports, press conferences, and youth congresses" were among the most important weapons of anti-colonial struggle, with world opinion and international law more than important than conventional military objectives. ${ }^{7}$ Hakan Thörn illustrates in his transnational history of the anti-apartheid movement that national liberation movements were centrally concerned with a "struggle for representation" that took

3 Quinn Slobodian, "Socialist Chromatism: Race, Racism and the Racial Rainbow in East Germany," in Comrades of Color: East Germany in the Cold War World, ed. Quinn Slobodian (New York: Berghahn Books, 2015), 32.

4 See, for example, Gregory Witkowski, "Between Fighters and Beggars: Socialist Philanthropy and the Imagery of Solidarity in East Germany," in Comrades of Color: East Germany in the Cold War World, ed. Quinn Slobodian (New York: Berghahn Books, 2015).

5 Simon Huxtable, "Making News Soviet: Rethinking Journalistic Professionalism after Stalin, 1953-1970," Contemporary European History 27 (2018): 59.

6 George Roberts, "Press, Propaganda and the German Democratic Republic's Search for Recognition in Tanzania, 1964-72," in Warsaw Pact Intervention in the Third World: Aid and Influence in the Cold War, ed. Natalia Telepneva and Philip Muehlenbeck (London: I.B.Tauris, 2018), 151. 7 Matthew Connelly, A Diplomatic Revolution: Algeria's Fight for Independence and the Origins of the Post-Cold War Era (New York: Oxford University Press, 2003), 4. 
place in a "transnational media space."8 In this space, partisan socialist journalists were important actors to be utilized by anti-colonial forces.

It was events across the continents of Africa and Asia which sparked the growth of an extra-European-centered solidarity culture in the GDR, specifically the acceleration of decolonization in the early 1960s. This acceleration led GDR elites to believe that they were entering what Politburo member Hermann Axen would later call a "new revolutionary moment." 9 The states produced by this new revolutionary moment were not simply potential allies for the socialist world, but rather viewed as being "objectively anti-imperialist" according to Soviet premier Nikita Khrushchev. ${ }^{10}$ As a Soviet academic wrote at the time, "the national liberation movement is an inseparable part of the world revolutionary process."

In the GDR, the state made a concerted effort to depict Africa as a site of friendly, revolutionary, anti-imperialist movements and peoples, educating its citizens both about the existence of this revolutionary world and their need to practice solidarity with it. Erich Honecker, the General Secretary of the ruling Socialist Unity Party of Germany (SED), frequently boasted to African leaders that they were popular figures in the GDR: despite geographical distance, as he told Ethiopian leader Mengistu Haile Mariam in 1978, "socialist Ethiopia is close and dear to every citizen of our country."12 A year earlier, Joachim Yhombi-Opangothe head of state of the Marxist-Leninist People's Republic of the Congo-had traveled to East Berlin, where Honecker assured him that he was a household name. "In our country," he told the Congolese leader, "it is very well known how much the People's Republic of the Congo is doing for the final liberation of the African Continent from colonialism and racism." ${ }^{13}$ As Honecker would go on to tell Yhombi-Opango, he was not the only African leader to play a prominent role in everyday life in the GDR, noting that streets and buildings in the

8 Håkan Thörn, Anti-Apartheid and the Emergence of a Global Civil Society (Basingstoke: Palgrave Macmillan, 2006), 17.

9 Hermann Axen and Harald Neubert, Ich war ein Diener der Partei: autobiographische Gespräche mit Harald Neubert (Berlin: Edition Ost, 1996), 400.

10 Donald S. Carlisle, "The Changing Soviet Perception of the Development Process in the AfroAsian World,” Midwest Journal of Political Science 8 (1964): 386.

11 Cited in Roger E. Kanet, "Soviet Propaganda and the Process of National Liberation," in The Soviet Union, Eastern Europe and the Third World, ed. Roger E. Kanet (Cambridge: Cambridge University Press, 1987), 91.

12 SAPMO-BArch, DY 30/2419, “Toast während des Essens zu Ehren Mengistu Haile Mariam,” 1. 13 SAPMO-BArch, DY 30/2459, “Toast des Generalsekretärs des ZK der SED und Vorsitzenden des Staatsrates der DDR, Erich Honecker”, 31. 
country had recently been named after Patrice Lumumba, Amílcar Cabral, and another Congolese Marxist, Marien N'Gouabi. ${ }^{14}$

This chapter will analyze this depiction both on screen and in text, focusing on the output of a figure whose work spanned both media forms: Ulrich Makosch. It will show how GDR media sought to elide distance between Africa and the GDR, while at the time reproducing gendered and othering depictions which distanced the continent from the East German state. In particular, it will focus on the output from a trip Makosch made as a guest of the Mozambique Liberation Front (FRELIMO) to Tete province in the early 1970s, which resulted in several articles, a book, and three documentaries. This output represented both sides of the dual role taken on by socialist foreign reporters in this era: created both as propaganda for GDR citizens at home and as an object of international diplomacy. As we will see, Makosch's work ultimately proved to be more successful as the latter than the former.

\section{Depicting a Revolutionary World: GDR Foreign Reportage}

How were different media to present this image of Africa to the GDR population? Each one, as former Socialist Unity Party (SED) propaganda chief Werner Lamberz noted in 1976, had "its own place, its own specific potential impact. Together they form our reliable ideological orchestra. And in opposition to certain composers, we prefer neither the strings nor the brass, nor also the flutes. The Party's score has enough notes for all." 15 The orchestral metaphor, of course, depends on absolute state control of media sources. In societies where media is subject to competition (or, as is often the reality, oligarchic monopoly), newspapers and television often exist in competition with one another. But in the GDR, the different sections of media were merely different outlets of the same body sharing the same message, meaning that their different attributes came into sharper focus.

For GDR propagandists keen to efface the geographical space between the GDR and national liberation movements abroad, television and film were exciting media. They were also vital weapons in the struggle for national liberation, with movements such as FRELIMO using radical filmmaking in order to garner solidarity across continents. As Radina Vučetić has shown in the case of Yugo-

14 Ibid., 33.

15 SAPMO-BArch, DY 30/477, "Schlusswort des Genossen Werner Lamberz," 1-2. 
slavia, FRELIMO had been cooperating with foreign socialist powers in order to produce propaganda films since the late 1960s if not earlier. ${ }^{16}$ Beyond the socialist world, R. Joseph Parrot has highlighted the influence of Robert Van Lierup's A Luta Continua (The Struggle Continues), a collaborative film produced with FRELIMO, which played an instrumental role in the growth of African American solidarity with liberation movements in Southern Africa. ${ }^{17}$

In an often isolated GDR, television could elide distance, thus domesticating the political vision of socialist internationalism and translating grand ideology into everyday entertainment. In this regard, news programming was naturally seen to have a hugely important role. In terms of timescales of appearance, the development of news programming in the GDR largely mirrored West Germany (the Federal Republic, or FRG): the GDR state broadcaster Deutscher Fernsehfunk's (DFF) flagship newscast Aktuelle Kamera (Current Camera) first aired in December 1952 with a report on Stalin's birthday, with daily broadcasts beginning in 1957. The West German Tagesschau premiered five days after Aktuelle Kamera and began appearing daily in 1956. The content of the two programs was different, however, both in form as well as focus. Communist news bore its own very specific temporality. Domestic news was often thematically planned weeks or months in advance: the front pages of the SED's official newspaper, the Neues Deutschland, usually covered statements from party officials and reported breakthroughs or economic achievements, official celebrations or anniversaries, or party functions. ${ }^{18}$ In theory, one might expect foreign news reportage to be different: more reactive, or guided by events, and of course, more unpredictable. But foreign news could also be selective: reports on the capitalist world focused on poverty, drug addiction, weapons-trading and the far right, drawn together with anti-imperialist developments worldwide. As author and television critic Uwe Johnson once summarized, communist news was "news regarding the advantages of the East and the disadvantages of the West."19

DFF polling of citizens' views on television, so-called Sofortresonanzen ("immediate response") often picked up criticisms regarding GDR television's selectivity in this regard. One, from January 1969, noted that three different respondents had demanded that Aktuelle Kamera-which focused on the socialist and

16 Radina Vučetić, "We Shall Win: Yugoslav Film Cooperation with FRELIMO," Revista Crítica de Ciências Sociais 118 (2019).

17 R. Joseph Parrott, “A Luta Continua: Radical Filmmaking, Pan-African Liberation and Communal Empowerment,” Race \& Class 57 (2015).

18 On the Soviet case, see Huxtable, "Making News Soviet," 66.

19 Cited in Knut Hickethier, Geschichte der Fernsehkritik in Deutschland (Baden-Baden: Sigma, 1994), 88. 
anti-imperialist world-showed more reports from "all of the world," the clear implication and emphasis on the word "all" suggesting that what was really meant was the West. $^{20}$ We should, of course, be wary of presenting this as a cut-and-dried case of socialist propaganda in contrast to journalistic integrity in the West. Instead, the question of comparison is better thought of in terms of form. Socialist media systems might not have been more political than capitalist media, if such calculation were meaningful or indeed possible. But socialist media was intentionally political and those who controlled it imbued it with explicitly political purposes. Discussing the East German state film studio DEFA, for example, Seán Allan and Sebastian Heiduschke argue that to describe film as a propaganda tool is reductive, but that is very literally how film, alongside other media, was understood, at least by those in charge. ${ }^{21}$ Socialist media systems were defined by the Leninist notion of "agitprop": propaganda explains the "capitalistic nature of crises," agitation rouses the masses to action. ${ }^{22}$ As Kristin Roth-Ey explains in her history of Soviet television, the mass media boom in the Soviet Union was similar to that in the West, but the socialist ideal of culture was a key differentiating factor; communist culture was elitist and pedagogical because it saw itself as carrying out a spiritual mission of cultural uplift. ${ }^{23}$ At the same time, it is misleading to speak, as Kochanowski, Trültzsch and Viehoff do, of "political indoctrination." ${ }^{24}$ The goal of socialist media was, rather, to create independent and ideologically literate socialist subjects.

\section{Ulrich Makosch and Mozambique}

As the GDR's best known foreign correspondent, Ulrich Makosch was one of the foremost examples of this media landscape. As the DFF's chief foreign correspondent from 1965 until 1971 and then the face of Objektiv, the GDR's weekly political television program based on foreign affairs and international news, Ma-

20 BArch, DR 8/131, “Ergebnisse der 2. (26.) Sofortresonanz vom 25 Januar 1969,” Anhang, 1. 21 Seán Allan and Sebastien Heiduschke, "Introduction," in Re-Imagining Defa: East German Cinema in Its National and Transnational Contexts, ed. Seán Allan and Sebastian Heiduschke (New York: Berghahn Books, 2016), 5.

22 See especially Chapter 3 of V. I. Lenin, What Is to Be Done? (Harmondsworth: Penguin, 1988).

23 Kristin Roth-Ey, Moscow Prime Time: How the Soviet Union Built the Media Empire That Lost the Cultural Cold War (Ithaca: Cornell University Press, 2011).

24 Katja Kochanowski, Sascha Trueltzsch, and Reinhold Viehoff, "An Evening with Friends and Enemies: Political Indoctrination in Popular East German Family Series," in Popular Television in Eastern Europe During and Since Socialism, ed. Timothy Havens and Kati Lustyik (London: Routledge, 2013). 
kosch was a prominent exponent of the GDR's state-led Afrikabild. He also served on the board of the GDR-Mozambique Friendship Committee, a state-led organization consisting of various journalists, politicians, and other public figures which existed to promote GDR-Mozambique relations, and was a prolific author of African and Asian travelogues. Born in Brandenburg in 1933, Makosch studied journalism at the Karl Marx University in Leipzig, joining the Journalists Union (Verband der Journalisten der DDR, or VDJ) in 1952 and graduating in 1955. He began work in local radio as an editor at the Landessender Schwerin where he worked from 1955 to 1956, when he became editor and travel correspondent for the national broadcasting committee. He joined the SED in 1963, and in 1965 became radio and television correspondent for the DFF in Asia, based in Jakarta, before being forced to leave for Singapore in 1968 following Suharto's takeover. ${ }^{25}$ His early books and reportage were travel reports from Asia: featuring Japan (Heute in Japan: Aufgezeichnet zwischen Tokio und Hiroschima, 1959), multiple Asian countries (Zwischen Fudschijama und Himalaja, 1963, and Jahre in Asien, Eindrücke und Begegnungen, 1970), and Ceylon (now Sri Lanka) (Paradies im Ozean: Begegnungen in Ceylon, 1966).

Makosch moved away from foreign based reportage in the 1970s, taking key editorial roles in Berlin. He became editor in chief of reportage and documentaries at the DFF in 1972, editor-in-chief of Aktuelle Kamera in 1975, and a member of the SED district leadership in Berlin in 1976. At the same time, his focus switched to events in Southern Africa and became more explicitly political. Both of these shifts were the result of the marriage of personal circumstances and broader political changes in the GDR. The mid- to late 1970s were the heyday of internationalist solidarity in the country. Honecker's ascendance as leader preceded the collapse of the Hallstein doctrine and the entrance of the GDR and the FRG into the United Nations, leading to widespread diplomatic recognition. ${ }^{26}$ Many scholars have claimed that the GDR's emphasis on discourses of international solidarity existed as a means to circumvent diplomatic isolation: ${ }^{27}$ paradoxically, however, the discourse of solidarity actually grew following wide-

25 See a letter regarding Makosch's redeployment, SAPMO-BArch, DR 8/362, Letter from Adamek to Kiesewetter, July 2, 1968.

26 The Hallstein doctrine was a West German foreign policy principle which stated that the FRG would not maintain or establish relations with any nation that recognized the GDR. It was largely successful in preventing widespread diplomatic recognition of the GDR until it was abandoned in favor of Ostpolitik in the early 1970s. See Rüdiger Marco Booz, Hallsteinzeit: Deutsche Aussenpolitik 1955-1972 (Bonn: Bouvier, 1995).

27 For an illustrative example, see Toni Weis, "The Politics Machine: On the Concept of 'Solidarity' in East German Support for SWAPO,” Journal of Southern African Studies 37 (2011): 362. 
spread recognition. As Gregory Witkowski has shown, usage of the term "solidarity" in the GDR press peaked in 1973, the same year as entrance to the UN. ${ }^{28}$

Makosch's rise to prominence also coincided with an increased focus on Lusophone Africa in the GDR. Portuguese efforts to hold on to their colonial possessions in Angola, Guinea-Bissau, and Mozambique had faced armed insurgency since the early 1960s, but events came to a head in terms of international attention in the 1970s. Tanzania-which bordered Mozambique and had seen an influx of Mozambican refugees since the beginning of the anti-colonial insurgency-was an important site of entanglement for the GDR and FRELIMO. GDR officials had maintained relations with Lusophone resistance movements since the mid-1960s, especially through its consulate in Dar es Salaam, which, as Eric Burton has shown, became a hub for revolutionaries and the leaders of national liberation movements in this period. ${ }^{29}$ The existence of a GDR consulatewhich had survived Julius Nyerere's abortive diplomatic recognition of the country-meant that GDR diplomat Helmut Matthes was able to meet and establish links to these movements, including FRELIMO, the Angolan MPLA, and the Guinean PAIGC in the 1960 s. $^{30}$ Peter Spacek, a reporter with the East German state news agency, the Allgemeiner Deutscher Nachrichtendienst (ADN), was also based in Dar es Salaam from 1965 and reported for the Neues Deutschland on developments in Tanzania and East Africa. Spacek's reports often relied upon contacts and bulletins from national liberation movements based in the city during that period, which included FRELIMO, the South African ANC, Namibian SWAPO, as well as the Zimbabwean organizations ZAPU and ZANU and the head of the Angolan MPLA, Agostinho Neto. ${ }^{31}$

28 Witkowski, "Between Fighters and Beggars: Socialist Philanthropy and the Imagery of Solidarity in East Germany," 73.

29 Eric Burton, "Hubs of Decolonization. African Liberation Movements and 'Eastern' Connections in Cairo, Accra, and Dar es Salaam," in Southern African Liberation Movements and the Global Cold War "East": Transnational Activism 1960-990, ed. Lena Dallywater, Chris Saunders, and Helder Adegar Fonseca (Boston, MA: De Gruyter Oldenbourg, 2019), 47-55; See also Andrew Ivaska, "Movement Youth in a Global Sixties Hub: The Everyday Lives of Transnational Activists in Postcolonial Dar es Salaam," in Transnational Histories of Youth in the Twentieth Century, ed. Richard Ivan Jobs and David M. Pomfret (London: Palgrave Macmillan UK, 2015), 188-210. 30 Matthias Voß and Helmut Matthes, "Die Beziehungen DDR - VR Mosambik zwischen Erwartungen und Wirklichkeit,” in Wir haben Spuren hinterlassen!: die DDR in Mosambik: Erlebnisse, Erfahrungen und Erkenntnisse aus drei Jahrzehnten, ed. Matthias Voß (Münster: LIT Verlag, 2005), 15.

31 Peter Spacek, "Mit der FRELIMO im Busch," in Wir haben Spuren hinterlassen!: die DDR in Mosambik: Erlebnisse, Erfahrungen und Erkenntnisse aus drei Jahrzehnten, ed. Matthias Voß (Münster: LIT Verlag, 2005), 47. 
In the early 1970s, these links would be exploited to great effect as a newly confident, internationally recognized GDR expanded its international influence, and organizations such as FRELIMO increasingly sought to bring their struggles to international attention. A key feature of FRELIMO propaganda at this time was an emphasis on "liberated zones": areas of northern Mozambique that the organization claimed to have liberated from colonial rule. Photography and film were important means through which these liberated zones could be depicted. As Drew A. Thompson has shown, FRELIMO's Dar es Salaam-based Department of Information and Propaganda placed particular importance on photography: as a FRELMO photographer would later explain, sending photographs "all over the world ... was necessary to make [audiences] understand the objectives of our struggle." 32 In this regard, the work of foreign photographers in liberated areas was particularly valuable due to FRELIMO's self-perceived deficits in both equipment and credibility, turning "propaganda," as Thompson puts it, into "information." 33

Foreign press visits to liberated zones were a constant feature in Mozambique Revolution, FRELIMO's English-language periodical which was published in Dar es Salaam using a printing press donated by Finnish students from 1963-1975. The periodical was intended for an international audience, and visitors came from across the globe, including West Germany, the United Kingdom, Canada, and Italy. Official state visits were limited to the socialist countries, however. The December 1969 edition of Mozambique Revolution reported messages of solidarity sent to FRELIMO by the GDR's Afro-Asian Solidarity Committee and reports of a FRELIMO delegation visit to the GDR in June. ${ }^{34}$ The next edition, from March 1970, featured a report from Peter Spacek, who had traveled to a liberated zone and proudly proclaimed himself to be the "first German to visit the free part of Mozambique.” While there, Spacek reported witnessing a West German-produced military plane, a Dornier DO 27, drop bombs on civilians. ${ }^{35}$

The intra-German conflict was, of course, a key theme of GDR propaganda efforts, especially in the era of the Hallstein doctrine. What may have otherwise been an obscure provincial European conflict to FRELIMO was made important, however, by West German relations with Portugal, which had grown throughout the 1960s to encompass a significant amount of Portuguese arms imports and

32 Drew A. Thompson, “Visualising FRELIMO’s Liberated Zones in Mozambique, 1962-1974," Social Dynamics 39 (2013): 28.

33 Ibid., 29.

34 Mozambique Revolution, no. 41, October - December 1969, 38.

35 Mozambique Revolution, no. 42, January - March 1970, 17. 
foreign investment. ${ }^{36}$ During the early 1970s, a key FRELIMO demand was West German divestment from the Cahora Bassa dam project: international pressure had already forced Swedish and British companies to withdraw from the scheme. ${ }^{37}$ According to Mozambique Revolution, not only were German companies providing key services in the construction of the dam, but there were also widespread campaigns to settle white Europeans-including West Germanson the arable lands that would be created by the project. ${ }^{38}$

In the immediate period following the election of Willy Brandt as Chancellor in 1969, FRELIMO reached out to the West German leader, hoping to persuade him to draw back FRG support for Portugal. ${ }^{39}$ Although these efforts were unsuccessful, grassroots support for the national liberation movements in Lusophone Africa among the membership of Brandt's party, the SPD, did lead to a FRELIMO delegation visiting Bonn in July 1973. SPD support did not mean government support, however, and the FRELIMO delegation, led by vice-president Marcelino dos Santos, left Germany disappointed by their inability to extract concrete assurances on Cahora Bassa or official recognition of FRELIMO as government in exile. ${ }^{40}$

The summer of 1973 saw FRELIMO come more firmly down on the side of the socialist camp. A June 1973 article in Mozambique Revolution delineated a hierarchy of international solidarity, with African nations at the top, and the socialist camp coming in a close second: "Africa is leading the solidarity movement," the article claimed, but the "Socialist countries have also increased their support. Although far from meeting our needs, this support has played a very important role in our successes." ${ }^{41}$ It was in this atmosphere of increased cooperation that Ulrich Makosch began to focus on Mozambique in the summer of 1973. His first mention of events in Africa in the Neues Deutschland came on July 20. An ADN report entitled "GDR Journalists visited the site of Portuguese massacre" detailed a press conference held by a delegation of the GDR Journalist's Union in Lusaka, Zambia, in which Makosch, as the leader of the delegation, stated that

36 As Luís Nuno Rodrigues has shown, West Germany became a key supplier of arms for Salazar's Portugal in the 1960s, filling a gap created by John F. Kennedy's (short-lived) withdrawal of US support for the regime. Luís Nuno Rodrigues, "The International Dimensions of Portuguese Colonial Crisis," in The Ends of European Colonial Empires: Cases and Comparisons, ed. Miguel Bandeira Jerónimo and António Costa Pinto (London: Palgrave Macmillan, 2016), 257-261.

37 Mozambique Revolution, no. 42, January - March 1970, 30 - 32.

38 Mozambique Revolution, no. 45, October - December 1970, 14.

39 Rui Lopes, West Germany and the Portuguese Dictatorship, 1968-1974: Between Cold War and Colonialism (London: Palgrave Macmillan, 2014), 20.

40 Ibid., 225-227.

41 Mozambique Revolution, no. 55, April - June 1973, 1. 
he had visited the charred remains of a village in Mozambique whose inhabitants had been murdered by colonial troops. Having traveled to the country on a twoweek "information trip," Makosch also asserted that he had met 68 children in an orphanage, and uncovered evidence that Portuguese troops were being supported by Rhodesian and South African units. ${ }^{42}$ The date of Makosch's claims was interesting, coming seven months after the Wiriyamu massacre, which occurred in December 1972, and just ten days after the massacre was first reported in the Western press, in the Times, on July 10, $1973 .{ }^{43}$ The Times report came from a former British missionary, Adrian Hastings, who had received the information via survivors who had reported the massacre to local Spanish missionaries. ${ }^{44}$ When Makosch's account of the trip was later published in book format, however, the book only mentioned the burnt remains of a village "where the inhabitations appeared to have got out just in time." 45 It seems the intention of the Neues Deutschland article was to suggest that Makosch had visited Wiriyamu: in his later published book, Makosch mentions the outcry regarding Wiriyamu following Hastings' report, but does not claim to have visited the site himself.

This book, entitled The Girl from the Zambezi, [Das Mädchen vom Sambesi] was based on Makosch's experiences in Mozambique in the summer of 1973, when he traveled as part of a three man team to the liberated zone of Tete to collect material for work that would span the GDR media landscape, including film, articles in the East German press, and an article for Mozambique Revolution. ${ }^{46}$ Makosch's account of his trip, adapted from articles in Neues Deutschland and other journals, appeared as the first monograph in a new series of "current-political” texts from Leipzig publisher F. A. Brockhaus in early 1975, just months before Mozambique achieved formal independence in June. A review in the Neues Deutschland praised its accounts of personal encounters with both ordinary people and FRELIMO leaders and the "self-sacrificing struggle" against the colonial regime, claiming that it "explains the issues of the national liberation movements in concrete detail." 47

42 "DDR-Journalisten waren am Ort portugiesischer Massaker”, Neues Deutschland, July 20, 1973, 5.

43 On the massacre, see Mustafah Dhada, The Portuguese Massacre of Wiriyamu in Colonial Mozambique, 1964-2013 (London: Bloomsbury Publishing, 2017).

44 "Portuguese massacre reported by priests", The Times, July 10, 1973, 1.

45 Ulrich Makosch, Das Mädchen vom Sambesi (Leipzig: F. A. Brockhaus, 1975), 9.

46 Mozambique Revolution, no. 56, July - September 1973, 14.

47 "Start zur aktuell-politischen Reihe bei F. A. Brockhaus", Neues Deutschland, May 21, 1975, 14. 
In the book, Mozambique was presented as being both at the center of a global socialist community, but also fundamentally different: both distant and close. In an article written following the end of the Cold War, Makosch admitted to knowing very little "about Mozambique, about the structure of FRELIMO, or the different influences in this African area of tension" at the time. ${ }^{48}$ What followed from this was a work of representation: of Makosch's experiences in Mozambique, but also of the wider significance of events in Mozambique for the socialist world. For Samora Machel, the leader of FRELIMO, these issues of representation were central to revolutionary praxis. In conversation with Erich Honecker later in the decade, Machel complained that

[w] hen people speak of Africa, they often have a particular notion. It is one that says: we will help the Africans. The African is one who lives in misery, walks barefoot, is plagued by illness, who walks through the desert. That is to say that the image of the African is a timeless one, one rooted in the past. When European tourists come here, they want to take photos. But when they see me, they aren't interested, because I wear a suit and tie: I am not African enough. They want to see Africans whose ribs can be counted, who are hungry, dirty, and barefoot. This mentality has still not been dispelled..$^{49}$

As Gregory Witkowski has argued, GDR solidarity campaigns towed a thin line between emphasizing the "superiority of the donor as much as the bond of solidarity between donor and recipient," depicting non-white recipients as somewhere between "fighters and beggars." 50 In his literature and prodigious literary output on Mozambique, Makosch towed this same line, claiming that he "experienced Africa, in pain, sorrow and confidence and with the smile of victory."51

In the text's opening pages, the socialist optimism of the mid-1970s is palpable, with the GDR's new-found international confidence coinciding with the collapse of the Portuguese empire. Both the Carnation Revolution itself and the Marxist-inspired nature of the liberation movements that fought the Portuguese in Africa were a huge source of hope for GDR ideologues. Indeed, the impression made by the success of these movements was not limited to GDR apparatchiks:

48 Ulrich Makosch, "Was bleibt... Afrika in den Medien der DDR," in Engagiert für Afrika: die DDR und Afrika II, ed. Ulrich van der Heyden, Ilona Schleicher and Hans-Georg Schleicher (Münster: LIT Verlag, 1994), 267.

49 SAPMO-BArch, DY 30/2470, “Stenografische Niederschrift der offiziellen Gespräche des Generalsekretärs des ZK der SED, Genossen Erich Honecker, mit dem Präsidenten der Frelimo und der Volksrepublik Moçambique, Genossen Samora Machel, in Maputo, 22. Februar 1979”, 47. 50 Witkowski, "Between Fighters and Beggars: Socialist Philanthropy and the Imagery of Solidarity in East Germany.”

51 Makosch, Das Mädchen vom Sambesi, 13. 
as US international relations expert and future emeritus senior Hoover fellow Thomas H. Henriksen noted in 1978, the victories of PAIGC and FRELIMO could be interpreted as the "first successful indigenous Marxist revolutions accompanied by prolonged fighting not growing directly from the conditions of international war." 52 These successes also fit into a pattern discerned by GDR foreign policy experts in the 1970s. Hermann Axen later remembered that the Portuguese revolution had played "an important role" in elite thinking: not only had it shown that revolution could take place in a small, agrarian country, but it had also been led by a small group of army generals. These developments were part of a broader global trend, Axen noted, that "appeared to show was that we were arriving at a new moment, where not only the intellectuals, but also the military were joining the revolutionary movement-Nasser in Egypt, Assad in Syria, the Portuguese military." ${ }^{33}$ Makosch himself played an important role in articulating the importance of Portugal to GDR audiences, appearing on a program in 1974 to outline "how this victory of the democratic forces in Portugal became possible, and what difficulties still exist in consolidating the progressive forces." 54

The opening passages of Makosch's book show this revolutionary optimism through the prism of transnational linkage. In the opening scene, Makosch discusses attending the founding of the PAIGC's youth organization in newly freed Guinea-Bissau with Soviet, Portuguese, Guinean, and Mozambican comrades:

And while we all still carried the red dust of the runway in Guinea on our face and in our hair, one of us... gave a spontaneous comparison of the stone thrown into the water, generating waves, which in turn produce further waves on the far shore. This refers to the emergence of the states of the socialist community with the Soviet Union at the head, the emergence of revolutionary-democratic governments such as in Tanzania and Guinea, which in turn made the stream of solidarity for the national liberation movements more powerful, a struggle which has now led to success. ${ }^{55}$

Such a metaphor was typical of the confidence of the socialist 1970s: highlighting the power of transnational effects; the vital, if not always clearly perceptible role played by socialist movements in the success of national liberation movement, while always making sure to note the key role played by the Soviet Union. It was also typical of a certain socialist "mooring" in the decade: the

52 Thomas H. Henriksen, “Marxism and Mozambique,” African Affairs 77 (1978): 441.

53 Nasser had actually died in 1970, but his successor, Anwar Sadat, was also a member of the military. Axen and Neubert, Ich war ein Diener der Partei, 401.

54 "Information und Eindruck", Neues Deutschland, June 25, 1974.

55 Makosch, Das Mädchen vom Sambesi, 10-11. 
fleeting collision of state-socialist confidence and national liberation in Lusophone Africa. Later, Makosch notes, the group "hear the historic speech of Brezhnev, and over the long distance his voice penetrates into the camp of Madina do Boe, a greeting to the peoples of Africa." ${ }^{56}$

The world-historical importance of developments in Lusophone Africa was a key element of Makosch's account here, noting that the "last two decades have seen my journalistic work take me to various showplaces of international events in Asia and Africa: to the culminating points in the result of the interaction of the revolutionary mainstreams, as in Vietnam, as in Mozambique, as a witness of anti-colonialist revolutions, which themselves became powerful accelerators of modern history." ${ }^{57}$ Makosch was keen to highlight the GDR's role in these events. In keeping with GDR solidarity discourses, notions of development were prominent: "Earlier, every serious illness led to death. There is a hospital with a grass roof now. For almost 400 years here, there was no development to speak of." ${ }^{58}$ The pedagogical work of FRELIMO was also a key focus. Here again, the GDR's influence was felt strongly: "Here, that [freedom] means the overcoming of illiteracy and a real right to education. A maths course book, developed and printed with the help of the GDR, shows the power of the socialist community, here in a mountainous province." ${ }^{59}$ This form of cooperation would expand following Mozambican independence to encompass a wide variety of education exchange programs, as Marcia Schenck's chapter in this volume illustrates. One chapter of Makosch's text, entitled "Bridges of Solidarity," centered on this theme: the influence of the GDR framed through a developmentalist and "stageist" conception of history. Revealingly, Makosch quotes Marcus Mobote, then a commander with FRELIMO, who told him that "the medicine in our hospitals, some of the books in the schools, the material for our uniforms and much more-it comes from you." ${ }^{60}$ This claim is followed by a comparison of the two countries, which imagined similarities between anticolonial and antifascist struggle: "you have also liberated yourselves, many years ago. Now you govern yourselves, and can help us because you have built up your country... although you live far away, divided by the sea, you feel like us, think like us, and we have the same enemy." $" 61$

\footnotetext{
56 Ibid., 11.

57 Ibid., 11.

58 Ibid., 23.

59 Ibid., 23.

60 Ibid., 109.

61 Ibid.
} 
For Makosch, Mozambique was at the forefront of a global community of socialist struggle and development. Its struggles were closely tied to that of the GDR, but at the same time the text relies on gendered, othering tropes which present Mozambique as fundamentally foreign. On one level, this difference was articulated through age-old climatic stereotypes: Makosch frequently mentions the biting cold at night, something he admits he "never would have thought" was possible in Africa. ${ }^{62}$ Camera operator Hans Anderssohn was more explicit in his usage of the traditional tropes of Western charity, talking of children with "big eyes" who looked "sad and intimidated." ${ }^{63}$ Children featured heavily in the text, mostly as orphans who had lost parents to the Portuguese and were now under the care of FRELIMO: as we will see later, of all of Makosch's output, it was that which focused on children that was most successful among GDR viewers. As Makosch himself later noted, knowing very little about Mozambique, what struck him most upon arrival was the children: "That was the saddest thing I have had to view in my life... The children, many very small, some of them adolescents, had no shoes. They froze miserably in the night and in the mornings." 64

The title of Makosch's travelogue, The Girl from Zambesi, is a reference to a FRELIMO instructor named Evenia that Makosch met on the trail and to whom a chapter is devoted, as well as half of the front cover. At 18 years of age, Evenia had been with FRELIMO for three years when Makosch met her. Much of his introduction is based on her appearance: "I estimated then-she looked almost like a boy-that she was about 16." ${ }^{65}$ By contemporary standards, Evenia was a child soldier. She would have been one of many recruited by FRELIMO: almost half of the FRELIMO fighters questioned for a study in Mozambique's Manica province were younger than 18 when they joined the organization. ${ }^{66}$ At the time Makosch was writing, however, it was common for socialist writers to celebrate imagery of armed women and children engaged in political struggle: there is no sense in the text of any issue with Evenia's age. Conversely, as Harry G. West has shown, it was common at the time for female teenage and child soldiers to be celebrated in 1960s propaganda, making them "legends of them not only in southern Africa but, more broadly, among leftist and feminist

62 Ibid., 18.

63 "Kinder der FRELIMO”, Neues Deutschland, May 13, 1974, 7.

64 Makosch, "Was bleibt... Afrika in den Medien der DDR," 267.

65 Ibid., 30.

66 Jessica Schafer, "The Use of Patriarchal Imagery in the Civil War in Mozambique and Its Implications for the Reintegration of Child Soldiers," in Children and Youth on the Front Line, ed. Jo Boyden and Joanna de Berry (New York: Berghahn Books, 2004), 87. 
militants worldwide." ${ }^{\prime 67}$ Indeed, it was only in the 1980s and 1990s that the phenomenon of child soldiers began to take center stage in international human rights campaigns. One of the key architects of this new discourse was Graça Machel, former FRELIMO member and Mozambique's first Minister of Education and Culture, who authored an influential UN report on the issue in $1996 .{ }^{68}$

Makosch's description of Evenia is also typical of the focus on female fighters which dominated GDR coverage of national liberation struggles. Thanks in part to FRELIMO propaganda, women in Mozambique became international icons of revolutionary feminism in the 1960s. ${ }^{69}$ While throughout the book most of Makosch's conversations are with men, it is Evenia who gains prominence as a symbol and image. We are introduced to her as a "source of the excitement and attraction" in a FRELIMO camp. ${ }^{70}$ Her appearance is detailed much more than any of the men profiled, beginning with her face, which looked "like a particularly realistic Makonde woodcutting, a colorful cloth often covering frizzy hair... in her backpack, among a thousand other things, a mirror and a comb... and a machine gun over the shoulder."71

As Katrin Bahr shows in this volume, a refusal to engage with European colonial legacies-despite their anticolonial intentions-manifested in GDR citizens frequently reproducing the colonial gaze in Mozambique. ${ }^{72}$ Although the references to Evenia's appearance represent a typically European example of the male gaze, they stop short of the overt sexualization and exoticization seen in other GDR solidarity campaigns. ${ }^{73}$ Instead, Makosch is keen to present Evenia as a symbol of female emancipation: "calm and composed, passionate in discussions, self-sacrificing, friendly to us, tough when it comes to her opponents." Coded within this notion are a number of assumptions. Makosch initially presents Evenia as running the field kitchen, and moves on the later describe her running, to his surprise, a military maneuver. "Evenia works as an instructor

67 Harry G. West, "Girls with Guns: Narrating the Experience of War of FRELIMO's 'Female Detachment," in Children and Youth on the Front Line, ed. Jo Boyden and Joanna de Berry (New York: Berghahn Books, 2004), 112.

68 See Graça Machel, Impact of Armed Conflict on Children (New York: United Nations, 1996). 69 Kathleen E. Sheldon, Pounders of Grain: A History of Women, Work and Politics in Mozambique (Portsmouth, NH: Heinemann Educational Books, 2002), 142.

70 Makosch, Das Mädchen vom Sambesi, 29.

71 Ibid.

72 Bahr, this volume.

73 See, for example, depictions of Cuban women in the literature surrounding the practice of tourism to the island in George Bodie, “'It Is a Shame We Are Not Neighbours': GDR Tourist Cruises to Cuba, 1961-89," Journal of Contemporary History, August 28, 2019.

74 Makosch, Das Mädchen vom Sambesi, 30. 
here, accepted by all her male compatriots who find nothing wrong with it”, Makosch notes. ${ }^{75}$ Evenia's role is clearly portrayed as an outcome of FRELIMO's success: Makosch quotes a pamphlet he claims to have found in a village, which argues that in the colonial system women "were doubly exploited: first through the traditional society and second through the hungry capitalist regime, which gobbled up the material and cultural wealth of our people."76 This notion of a doubled exploitation was ironically a key theme of feminist literature in the GDR, which focused on the dual oppressions of workforce involvement and unpaid domestic labor, but this appears to pass Makosch by. ${ }^{77}$

The feminism presented in Makosch's text is clearly rooted in developmentalist conceptions of history: patriarchy was colonial, but also a remnant of feudalism. As Makosch writes, despite the overcoming of colonial forces, "there exists psychological factors which hold some women back from the realisation of their dreams: the inferiority complex, which resides in the conjunction of traditional worldviews and the colonial system."78 Evenia notes to Makosch that "contradictions" between men and women have existed for a long time, but she asks rhetorically if these are not "representative of the contradiction between the obsolete societal order and our lives?"79 When Makosch asks Evenia about the difficulties of commanding men, her answer is revealing: answering in the affirmative, she notes that her role "was probably only unusual for some at the beginning. Tradition and superstition are often just old habits, but our chairman, who spent some time in the GDR, said that it also wasn't easy there... and some people still do not quite understand it today." 80

Although Makosch's text was not guilty of a sexualized depiction of Evenia, her foregrounding raises questions. To a large extent, state-led feminism in the GDR, as Donna Harsch notes, retained the gender norms of previous social systems: and being state-led almost always meant being led by men. ${ }^{81}$ Scholars such as Celia Donert have alerted us to the previously underexamined importance that official (and, to a lesser extent, unofficial) women's organizations

75 Ibid., 31.

76 Ibid.

77 On this, see Lorna Martens, The Promised Land?: Feminist Writing in the German Democratic Republic (New York: SUNY Press, 2001), 171-80.

78 Makosch, Das Mädchen vom Sambesi, 36.

79 Ibid., 31.

80 Ibid.

81 Donna Harsch, "Communism and Women," in The Oxford Handbook of the History of Communism, ed. Stephen A. Smith (Oxford: Oxford University Press, 2014), 488. 
played in the global Cold War. ${ }^{82}$ But the patriarchal nature of socialist power structures meant that official feminist discourses emanated from male voices as much as, if not more than, female ones. Because foreign reporters and journalists in the GDR tended to be men, the focus on female emancipation in Africa thus came almost exclusively from male voices.

Makosch's text is a striking example of this ventriloquism: references to interpreters in the text make it unlikely that Makosch understood or could speak Portuguese, but large sections of the book consist of direct quotations from his subjects, and these quotations often sound remarkably similar to the Party (in this case, either FRELIMO or the SED) line. ${ }^{83}$ Evenia's notion of a double oppression under patriarchy and colonialism was also a theme for Samora Machel, who claimed in 1973 that "Generally speaking, women are the most oppressed, humiliated, and exploited beings in society. A woman is even exploited by a man who is himself exploited, beaten by the man who is lacerated by the palmatoria, humiliated by the man who is crushed under the boot of the boss and the settler." ${ }^{84}$ In a particularly jarring example of this ventriloquism, a 1972 text was published featuring writing from Makosch and three other male writers entitled "Salaam Fatima! Women of an Awakening World" [Salaam Fatima! Frauen der erwachenden Welt], focusing on "women's issues in Africa, Asia and Latin America" and heavily illustrated with pictures. ${ }^{85}$ This, of course, was a world in which the punishment for a television presenter deemed to have crossed the line in making sexist remarks on air was to be summoned to the office of a male boss and given a copy of August Bebel's Women and Socialism, as happened to Heinz Quermann: that is to say, not one where issues of representation or female voices were often considered in any great detail. ${ }^{86}$

82 Celia Donert, "Feminism, Communism and Global Socialism: Encounters and Entanglements," in The Cambridge History of Communism, Volume 2: Everyday Socialism and Lived Experiences, ed. Juliane Fürst, Silvio Pons, and Mark Selden (Cambridge: Cambridge University Press, 2017); Celia Donert, "From Communist Internationalism to Human Rights: Gender, Violence and International Law in the Women's International Democratic Federation Mission to North Korea, 1951," Contemporary European History 25 (2016).

83 Makosch, Das Mädchen vom Sambesi, 9.

84 Samora Machel, "The Liberation of Women is a Fundamental Necessity for the Revolution", https://www.marxists.org/subject/africa/machel/1973/liberation-women.htm, accessed December 15, 2019. I am grateful to Dr. Eric Burton for this reference.

85 Otto Marquardt et al., salaam fatima! Frauen der erwachenden Welt (Leipzig: F.A. Brockhaus, 1975).

86 Heather L. Gumbert, Envisioning Socialism: Television and the Cold War in the German Democratic Republic (Ann Arbor: University of Michigan Press, 2014), 115-16. 


\section{Africa on Screen: Socialist Internationalism as Entertainment}

Probably the most prominent outputs from Makosch's trip were three documentary films: "Mozambique - The Struggle Continues," [Der Kampf geht weiter] first screened on GDR television screens in September 1973 and later at the sixteenth International Leipzig Documentary and Short Film Week in late November; "FRELIMO's Children” [Kinder der FRELIMO], first screened on GDR television on May 14, 1974; and "Victors on the Zambezi" [Sieger am Sambesi], which focused on the challenges of the new Mozambican state and first aired, also on GDR television, on July 16, 1975. While the reception of his book is difficult to gauge, television audience research produced by the DFF provides some useful insight into the relative success-or otherwise-of Makosch's televisual output. ${ }^{87}$ As already noted, Makosch was an important figure within GDR foreign news journalism, which had grown from the late 1950s onward into a particularly important feature of television programming. As Heather Gumbert has shown, the state broadcaster in the GDR, the Deutscher Fernsehfunk, or DFF, had been chastised by the Politbüro for being outflanked and outpaced by Western news agencies in their coverage of the Hungarian uprising in $1956 .{ }^{88}$ From the late $1950 \mathrm{~s}$ onwards, then, there was an increased focus on "current-political" (aktuell-politisch) programming, with a particular emphasis on anti-imperialist struggle in Africa and the Middle East. ${ }^{89}$ This domestic development combined with events worldwide, where decolonization and the increasing momentum of various forms of national liberation were attracting the attention of the socialist state. The DFF were already demanding in 1958 that television raise awareness among the GDR population regarding "fraternal socialist countries."90

This focus lasted only a decade, however. It is a central claim of the historiography that from the late 1960s onward, GDR television moved toward a focus on entertainment as information and news-based programming failed to have

87 The qualitative data produced by such research comes with obvious reservations, but viewership figures would seem to relatively unproblematic. For a detailed discussion of Zuschauerforschung, see Michael Meyen, Einschalten, Umschalten, Ausschalten? das Fernsehen im DDR-Alltag (Leipzig: Leipziger Universitätsverlag, 2003), 18-29.

88 Gumbert, Envisioning Socialism, 71.

89 Ibid., 78.

90 Ibid., 142. 
the desired propagandistic effect. ${ }^{91}$ Michael Meyen's study of GDR television made similar findings via both interviews and contemporary viewer research. ${ }^{92}$ Claudia Dittmar traces this shift to the late 1960s and early 1970s, as does Heather Gumbert, citing a commonly quoted Honecker speech in 1971 which exhorted programmers to overcome a "certain boredom" among GDR viewers. ${ }^{93}$ As Sasha Trültzsch and Uwe Breitenborn have shown, the GDR television program corresponded similarly to other countries-including the FRG-in terms of genreshare by the 1970s, eschewing an earlier focus on factual programming. ${ }^{94}$

Despite the decline of factual programming, the DFF's own research convinced it that foreign news reportage remained both popular and important for GDR viewers. This was true of events close to home, such as the Prague Spring in 1968, which prompted a demand for more informational and educational programming in a similar fashion to the Hungarian uprising. ${ }^{95}$ But the GDR's growing international confidence and widespread optimism in the socialist world during the 1970s led to opportunities for more foreign news reporting in Africa too, of which Makosch's Mozambique films were a notable example. DFF researchers found that foreign reporting was the fourth most desired form of programming in the early 1970s, and that GDR-produced foreign reportage was lacking in the program, with existing foreign reportage-based programs proving popular. ${ }^{96}$

Makosch became Objektiv's frontman in the late 1960s, presiding over a slump in the show's viewership, from an average of 20.9 percent in 1968 to 8.2 percent in $1972 .{ }^{97}$ Given international events, one might have expected a growth in audience, but instead viewership declined throughout the decade,

91 Sascha Trültzsch and Reinhold Viehoff, "Undercover: How the East German Political System Presented Itself in Television Series," in Popular Television in Authoritarian Europe, ed. Peter Goddard (Manchester: Manchester University Press, 2013), 142. Carol Anne Costabile-Heming makes the same claim. See Carol Anne Costabile-Heming, "'Rezensur': A Case Study of Censorship and Programmatic Reception in the GDR,” Monatshefte 92 (2000): 54.

92 Meyen, Einschalten, Umschalten, Ausschalten?, 80.

93 Gumbert, Envisioning Socialism, 161.

94 Sasha Trültzsch and Uwe Breitenborn, "Program Structure Analysis of the GDR Television 1956 to 1991," Siegener Periodicum zur internationalen empirischen Literaturwissenschaft 25 (2006): 266.

95 Deutsches Rundfunk Archiv (hereafter DRA), H008-02-04-0023, “Analyse der Bisherigen Forschungsergebnisse zur Wirkung der Journalistischen Sendungen im Programm des Deutschen Fernsehfunks", 18-19.

96 Ibid., 51.

97 DRA, H074-00-02-0082, “Einige Ergebnisse zu Objektiv”, July 4, 1972, 1. 
continuing on a steady decline into the 1980 s. ${ }^{98}$ DFF reports noted that viewership was significantly higher among SED members. ${ }^{99}$ While Makosch's reportage was increasingly viewed as unpopular and messages regarding socialist internationalism were increasingly finding more traction via entertainment, GDR viewers were also increasingly getting their information and news from television. ${ }^{100}$ DFF leaders obviously hoped that films like Makosch's could fill this gap.

"The Struggle Continues" was the most heavily touted of the three films and appeared on GDR television screens first, on the important 8 p.m. slot on the DDR 1 channel on September 25, 1973. ${ }^{101}$ GDR press reported on its success with rapturous acclaim. "The documentary-maker's search for truth often goes hand in hand with unfamiliar physical efforts," a review of the film's first screening claimed: "Ulrich Makosch and Hans Anderssohn walked $200 \mathrm{~km}$ through hard-to-reach areas in an unfamiliar climate for their half-hour GDR feature film 'Mozambique - The Struggle Continues,' in constant danger of discovery by Portuguese colonial troops."102 Despite the fanfare, however, the initial screening defied the high expectations that earlier DFF reports had placed on foreign reportage. Research showed that only 5.5 percent of viewers watched the show, which was "well under the average for journalism in the Tuesday $8 \mathrm{pm}$ slot and well under the average for foreign reportage."103 These numbers were put down to the fact that the film had been screened at short notice and not widely advertised, and the report noted that those viewers who had seen the show evaluated it favorably. ${ }^{104}$ The film was screened again during the Christmas period and highlighted in a Christmas television guide in Neues Deutschland. ${ }^{105}$ This time round, however, viewership was even worse: audience researchers were unable to find a single viewer among their research subjects. ${ }^{106}$ The follow up film, "Victors on the Zambezi," which used Makosch's footage to

98 Klaus Behling, Fernsehen aus Adlershof: Das Fernsehen der DDR vom Start bis zum Sendeschluss (Berlin: Edition Berolina, 2016), 57.

99 DRA, H074-00-02-0082, "Einige Ergebnisse zu Objektiv”, 2.

100 DRA, H074-00-02-0082, "Zusammenfassende Darstellung aller bisherigen Erfahrungen der Zuschauerforschung auf dem Gebiet: Allgemeine Einstellungen zum Fernsehen und Probleme der Programmstruktur", May 1971, 4.

101 "Fernsehen Aktuell", Neues Deutschland, September 25, 1973, 6.

102 "In der vordersten Frontlinie des Klassenkampfes”, Neues Deutschland, 29.10.1973, 4.

103 DRA, H081-03-02-0053, “Ergebnisse der 39./193. Sofortresonanz vom 28.09.1973”, 16-17.

104 Ibid., $16-17$.

105 "Was es an den Festtagen zu sehen gibt”, Neues Deutschland, 12.12.1973, 4.

106 The film was screened on the GDR's less popular second channel this time round, but these numbers are nevertheless surprisingly low. DRA, H081-03-02-0053, "Ergebnisse der 52./206. Sofortresonanz vom 27.12.1953”, 16. 
put together a film anticipating the forthcoming Mozambican independence celebrations, also struggled to attract audiences despite media previews. ${ }^{107}$ Notably, a third film, "The Children of FRELIMO," which aired in May 1974 and focused on the orphans Makosch had encountered in Mozambique, received almost double the viewership of the previous two, at ten percent. ${ }^{108}$

The evidence suggests that Makosch's films were more important as objects of high diplomacy than a means of generating solidarity among the GDR population. In this regard there was a curious mirroring with the work of FRELIMO's Department of Information and Propaganda, which drew distinct lines between its domestic and international audiences, belying claims to transnational unity in the process. ${ }^{109}$ As the initial review of "The Struggle Continues" in Neues Deutschland noted, quoting Makosch's press briefing in Leipzig, the film was to serve the elision of distance between the GDR and FRELIMO, serving to "bring us closer to the fight of FRELIMO, allowing us to look into the faces of people who, because they love life, have learned not to fear death in battle."110 But it was also made to be used as propaganda for FRELIMO themselves, and thus as an instrument of the "solidaric unity" between the two sides. ${ }^{111}$

Makosch's visit to Mozambique's liberated zones came at a time of increased cooperation between FRELIMO and the GDR: the very existence of the trip and resulting film may have been more important than its reception in the GDR. In contrast with low viewership figures, the film was greeted with much international fanfare. At the 1973 Leipzig film week, which featured delegations from almost 40 nations, the film was well received, receiving a Silver Dove award. ${ }^{112}$ The Palestinian delegation to the festival awarded it the first "Palestine Prize," which was given to films "which depicted the struggle of a people against imperialism and whose struggle resembled that of the Palestinians." "113 Later reports suggested the film was sold to "many Asian and African nations" at the festival. ${ }^{114}$ In December Samora Machel (misspelt "Marchel” in the Neues Deutschland article

107 DRA, H081-03-02-0068, "Sehbeteiligung und -bewertung der Sendungen der 29. Woche", 3.

108 DRA, H081-03-02/0067, "Ergebnisse der 21. (227.) repräsentativen Umfrage vom 22. Mai 1974 ", 12.

109 Thompson, "Visualising FRELIMO’s Liberated Zones in Mozambique, 1962-1974," 38.

110 "In der vordersten Frontlinie des Klassenkampfes”, Neues Deutschland, 29. October 1973, 4. 111 Ibid., 4.

112 “Was es an den Festtagen zu sehen gibt”, Neues Deutschland, December 12, 1973, 4.

113 Nadia Yaqub, Palestinian Cinema in the Days of Revolution (Austin: University of Texas Press, 2018), 134.

114 “DDR-Künstler solidarisch mit den kämpfenden Völkern”, Neues Deutschland, December 29, 1973, 2. 
reporting the event) wrote a letter to Erich Honecker thanking him for the production of the film, which had been screened to a delegation consisting of the vice president of FRELIMO, the Tanzanian information minister, and the deputy General Secretary of the Organisation for African Unity National Liberation Committee at the tenth World Festival of Youth and Students in Berlin. ${ }^{115}$ Machel would note his gratitude to Honecker in person at a meeting in 1979, praising the "fruitful cooperation" that FRELIMO had with the journalists and press organs of the GDR, "who disseminated the news of our struggle" and noting that many of them, like Makosch, had "visited liberated areas and areas of conflict." 116 The impact of the film itself remained fleeting, a temporary act of solidarity, or mooring. It does not appear in a recent study of similar foreign-made films in Mozambique during this period by Ros Gray, for example, and references to it beyond the 1970s are difficult to find. ${ }^{117}$

\section{Conclusion}

Ulrich Makosch was a party journalist in the purest sense. His reporting on Africa, then, was political and pedagogical: it was agitprop, seeking to depict Africa as "close" to the GDR in the abstract. Makosch was deeply involved and implicated in some of the more unsavory implications of agitprop: in 1985, for example, he presented a Stasi-produced program entitled "Returned: Interviews with the Disillusioned” [Zurückgekehrt - Interview mit Enttäuschten], which featured interviews with people who had fled the GDR and returned, agreeing in arrangements with the Stasi to appear on the program in the hopes of a comfortable resettlement. ${ }^{118}$ Makosch himself was, for a number of years, an "IM" or unofficial collaborator with the Stasi, which was almost certainly a requirement of his role. Following the fall of the Wall, he renounced agitprop and spoke of being "ready, with pleasure to work along journalistic lines." ${ }^{119}$ He subsequently worked for US

115 "FRELIMO dankt DDR für Film über Befreiungskampf”, Neues Deutschland, December 20, 1973, 2.

116 SAPMO-BArch, DY 30/2470, "Stenografische Niederschrift der offiziellen Gespräche des Generalsekretärs des ZK der SED, Genossen Erich Honecker, mit dem Präesidenten der Frelimo und der Volksrepublik Moçambique, Genossen Samora Machel, in Maputo, 22. Februar 1979”, 42. 117 Ros Gray, Cinemas of the Mozambican Revolution (Woodbridge: James Currey, 2020), 15-64. 118 See https://www.stasi-mediathek.de/medien/propagandavideo-zurueckgekehrt-interviewmit-enttaeuschten-ueber-rueckkehrer-in-die-ddr/, accessed November 11, 2019.

119 “East Germany: Putting the Pieces Together Again”, Broadcasting, June 2, 1990, 55. 
broadcaster CNN for a couple of years. Freed from the dictates of GDR agitprop, Makosch's work saw a shift in register, highlighted by a contribution to an edited volume on GDR-Mozambican relations in 2005: in contrast to the air of impending victory found in his 1970s texts, Makosch spoke of encountering a "sad and tired existence" among Mozambicans in that period. ${ }^{120}$

If the newspaper was the dominant medium for foreign news reportage at the beginning of the GDR's existence, then television would have assumed this mantle by the end of its existence. Television, particularly on location filming, boasted an ability to sever the physical divisions between viewer and viewed. The German word for television, Fernsehen, is a calque derived from English, thus sharing its literal connotation of "distance viewing." The technical ability to remove distance, as the great theorist of television Raymond Williams noted, created specific forms of cultural power; during the Falklands War, Williams criticized a particular mode of distancing in contemporary coverage, which "distorts the imagination and permits the fantasies of models and of convictions without experience."121 Williams' concern was television's ability to create distance from reality and thus soften the effect of war, so that "the sovereign power to order war operates within the cultural power to distance.”122 Television abstracted what was real. Depictions of Africa in the GDR, conversely, began with an abstract ideal and sought to reify it. The GDR was a confined state, but one that imagined itself, through the medium of Marxist-Leninist theory, to be part of an objectively defined global political movement. Unlike the news reportage that Williams chastised, GDR television's depictions of this world thus sought to elide, rather than create, distance.

Ulrich Makosch's output on Mozambique was an important example of this attempt to create elision. In this sense, it was a paradoxical success. In a postWende evaluation of the GDR's Afrikabild, Makosch struck a largely defiant tone. If this image was to be criticized, Makosch noted, such criticism ought to center on its inability to draw out "differentiation," arguing that "great proximity and differentiation are usually mutually exclusive, an experience that is to be discerned in the African reporting of the GDR media." ${ }^{123}$ For Makosch, the problem was over-identification: "one suffered with the guest state," and fears regarding the utilization of criticism by mutual enemies led to the creation of

120 Ulrich Makosch, "Salz auf der Hand...," in Wir haben Spuren hinterlassen!: die DDR in Mosambik: Erlebnisse, Erfahrungen und Erkenntnisse aus drei Jahrzehnten, ed. Matthias Voss (Münster: LIT Verlag, 2005), 577.

121 Raymond Williams, “Distance,” London Review of Books, June 17, 1982, 20.

122 Ibid., 20.

123 Makosch, "Was bleibt...Afrika in den Medien der DDR," 275. 
an "idealised image." 124 The notion of such proximity reveals the mutual advantage found in foreign reportage between Makosch and his Mozambican partners: the importance of such reportage lay in the international sphere, in the transnational world of anti-imperialist politics. But this proximity was not reproduced on the domestic level: evident both in his othering and ventriloquizing of Mozambican subjects, and in the lack of success and viewership that Makosch's films found at home. In the end, elision worked only on an international level: preaching to the converted, but failing in its promise to bring the struggles of FRELIMO home for GDR citizens.

Such findings may not come as surprise to those familiar with the GDR's cultural output. "Nothing did more harm to the GDR," Stefan Wolle has claimed, "than its own propaganda." 125 But the failure of Makosch's work to have an impact at home challenges the usual assumptions regarding state-led cultures of solidarity in GDR, which have long been viewed as primarily existing to promote the state's legitimacy among the GDR population at large. The case here seems to indicate that rather than existing as a symbolic projection for a credulous East German public, the real importance of Makosch's work lay abroad. For the leadership of FRELIMO, figures such as Makosch were important weapons in the fight for international recognition and support. And for the exponents of international socialism in the 1970s, it seemed to confirm the growing strength of the socialist world. In the longer term, the importance of Makosch's work would prove fleeting, an imperfect mooring: the optimism of the early to mid-1970s dwindled toward the end of the decade as Mozambique and the GDR descended into civil war and a fiscal crisis respectively.

\section{Bibliography}

Allan, Seán, and Sebastien Heiduschke. "Introduction." In Re-Imagining Defa: East German Cinema in Its National and Transnational Contexts, edited by Seán Allan and Sebastian Heiduschke, 1-19. New York: Berghahn Books, 2016.

Axen, Hermann, and Harald Neubert. Ich war ein Diener der Partei: autobiographische Gespräche mit Harald Neubert. Rote Reihe. Berlin: Edition Ost, 1996.

Behling, Klaus. Fernsehen aus Adlershof: Das Fernsehen der DDR vom Start bis zum Sendeschluss. Berlin: Edition Berolina, 2016.

Bodie, George. “'It Is a Shame We Are Not Neighbours': GDR Tourist Cruises to Cuba, 1961-89:" Journal of Contemporary History, August 28, 2019.

124 Ibid., 275.

125 Stefan Wolle, Die heile Welt der Diktatur: Alltag und Herrschaft in der DDR 1971-1989 (Berlin: Links Christoph Verlag, 2013), 70. 
Booz, Rüdiger Marco. Hallsteinzeit: Deutsche Aussenpolitik 1955-1972. Bonn: Bouvier, 1995. Buchheim, Christoph. "Die Achillesferse der DDR - der Aussenhandel." In Überholen ohne einzuholen: die DDR-Wirtschaft als Fußnote der deutschen Geschichte?, edited by André Steiner, 91-103. Berlin: Ch. Links, 2006.

Burton, Eric. "Hubs of Decolonization. African Liberation Movements and 'Eastern' Connections in Cairo, Accra, and Dar es Salaam." In Southern African Liberation Movements and the Global Cold War "East": Transnational Activism 1960-1990, edited by Lena Dallywater, Chris Saunders, and Helder Adegar Fonseca, 25-56. Boston, MA: De Gruyter Oldenbourg, 2019.

Carlisle, Donald S. "The Changing Soviet Perception of the Development Process in the Afro-Asian World." Midwest Journal of Political Science 8 (1964): 385- 407.

Connelly, Matthew. A Diplomatic Revolution: Algeria's Fight for Independence and the Origins of the Post-Cold War Era. New York: Oxford University Press, 2003.

Costabile-Heming, Carol Anne. "'Rezensur': A Case Study of Censorship and Programmatic Reception in the GDR." Monatshefte 92 (2000): 53-67.

Dale, Gareth. Between State Capitalism and Globalisation: The Collapse of the East German Economy. Oxford: Peter Lang, 2004.

Dhada, Mustafah. The Portuguese Massacre of Wiriyamu in Colonial Mozambique, 1964-2013. London: Bloomsbury Publishing, 2017.

Donert, Celia. "Feminism, Communism and Global Socialism: Encounters and Entanglements." In The Cambridge History of Communism, Volume 2: Everyday Socialism and Lived Experiences, edited by Juliane Fürst, Silvio Pons, and Mark Selden, 399-421. Cambridge: Cambridge University Press, 2017.

Donert, Celia. "From Communist Internationalism to Human Rights: Gender, Violence and International Law in the Women's International Democratic Federation Mission to North Korea, 1951." Contemporary European History 25 (2016): 313-333.

Gray, Ros. Cinemas of the Mozambican Revolution. Woodbridge: James Currey, 2020.

Grieder, Peter. The German Democratic Republic. Basingstoke: Palgrave Macmillan, 2012.

Gumbert, Heather L. Envisioning Socialism: Television and the Cold War in the German Democratic Republic. Ann Arbor: University of Michigan Press, 2014.

Harsch, Donna. "Communism and Women." In The Oxford Handbook of the History of Communism, edited by Stephen A. Smith, 488-504. Oxford: Oxford University Press, 2014.

Henriksen, Thomas H. “Marxism and Mozambique.” African Affairs 77 (1978): 441-62.

Hickethier, Knut. Geschichte der Fernsehkritik in Deutschland. Baden-Baden: Sigma, 1994.

Huxtable, Simon. "Making News Soviet: Rethinking Journalistic Professionalism after Stalin, 1953-1970." Contemporary European History 27 (2018): 59-84.

Ivaska, Andrew. "Movement Youth in a Global Sixties Hub: The Everyday Lives of Transnational Activists in Postcolonial Dar es Salaam." In Transnational Histories of Youth in the Twentieth Century, edited by Richard Ivan Jobs and David M. Pomfret, 188-210. London: Palgrave Macmillan UK, 2015.

Kanet, Roger E. "Soviet Propaganda and the Process of National Liberation." In The Soviet Union, Eastern Europe and the Third World, edited by Roger E. Kanet, 84-121. Cambridge: Cambridge University Press, 1987. 
Klenke, Olaf. Ist die DDR an der Globalisierung gescheitert? : Autarke Wirtschaftspolitik versus internationale Weltwirtschaft; das Beispiel Mikroelektronik. Frankfurt am Main: Peter Lang, 2001.

Kochanowski, Katja, Sascha Trueltzsch, and Reinhold Viehoff. "An Evening with Friends and Enemies: Political Indoctrination in Popular East German Family Series." In Popular Television in Eastern Europe During and Since Socialism, edited by Timothy Havens and Kati Lustyik, 81-101. London: Routledge, 2013.

Lenin, V. I. What Is to Be Done? Harmondsworth: Penguin, 1988.

Lopes, Rui. West Germany and the Portuguese Dictatorship, 1968-1974: Between Cold War and Colonialism. London: Palgrave Macmillan, 2014.

Machel, Graça. Impact of Armed Conflict on Children. New York: United Nations, 1996.

Maier, Charles S. Dissolution: The Crisis of Communism and the End of East Germany. Princeton: Princeton University Press, 1999.

Makosch, Ulrich. Das Mädchen vom Sambesi. Leipzig: F. A. Brockhaus, 1975.

Makosch, Ulrich. "Salz auf der Hand..." In Wir haben Spuren hinterlassen!: die DDR in Mosambik: Erlebnisse, Erfahrungen und Erkenntnisse aus drei Jahrzehnten, edited by Matthias Voss, 577-580. Münster: LIT Verlag, 2005.

Makosch, Ulrich. "Was bleibt ... Afrika in den Medien der DDR." In Engagiert für Afrika: Die DDR und Afrika II, edited by Ulrich van der Heyden, Ilona Schleicher, and Hans-Georg Schleicher, 266-277. Münster: LIT Verlag, 1994.

Marquardt, Otto, Ulrich Makosch, Günter Nerlich, and Konrad Schmidt. salaam fatima! Frauen der erwachenden Welt. Leipzig: F.A. Brockhaus, 1975.

Martens, Lorna. The Promised Land?: Feminist Writing in the German Democratic Republic. New York: SUNY Press, 2001.

Meyen, Michael. Einschalten, Umschalten, Ausschalten? das Fernsehen im DDR-Alltag. Leipzig: Leipziger Universitätsverlag, 2003.

Parrott, R. Joseph. "A Luta Continua: Radical Filmmaking, Pan-African Liberation and Communal Empowerment." Race \& Class 57 (2015): 20-38.

Pugach, Sarah. "African Students and the Politics of Race and Gender in the German Democratic Republic." In Comrades of Color: East Germany in the Cold War World, edited by Quinn Slobodian, 131-157. New York: Berghahn Books, 2015.

Roberts, George. "Press, Propaganda and the German Democratic Republic's Search for Recognition in Tanzania, 1964-72." In Warsaw Pact Intervention in the Third World: Aid and Influence in the Cold War, edited by Natalia Telepneva and Philip Muehlenbeck, 148-173. London: I.B. Tauris, 2018.

Rodrigues, Luís Nuno. "The International Dimensions of Portuguese Colonial Crisis." In The Ends of European Colonial Empires: Cases and Comparisons, edited by Miguel Bandeira Jerónimo and António Costa Pinto, 243-268. London: Palgrave Macmillan, 2016.

Roth-Ey, Kristin. Moscow Prime Time: How the Soviet Union Built the Media Empire That Lost the Cultural Cold War. Ithaca: Cornell University Press, 2011.

Schafer, Jessica. "The Use of Patriarchal Imagery in the Civil War in Mozambique and Its Implications for the Reintegration of Child Soldiers." In Children and Youth on the Front Line, edited by Jo Boyden and Joanna de Berry, 87-104. New York: Berghahn Books, 2004.

Sheldon, Kathleen E. Pounders of Grain: A History of Women, Work and Politics in Mozambique. Portsmouth, NH: Heinemann Educational Books, 2002. 
Slobodian, Quinn. "Socialist Chromatism: Race, Racism and the Racial Rainbow in East Germany." In Comrades of Color: East Germany in the Cold War World, edited by Quinn Slobodian, 23-43. New York: Berghahn Books, 2015.

Thompson, Drew A. “Visualising FRELIMO’s Liberated Zones in Mozambique, 1962-1974.” Social Dynamics 39 (2013): 24-50.

Thörn, Håkan. Anti-Apartheid and the Emergence of a Global Civil Society. St Antony's Series. Basingstoke: Palgrave Macmillan, 2006.

Trültzsch, Sascha, and Reinhold Viehoff. "Undercover: How the East German Political System Presented Itself in Television Series." In Popular Television in Authoritarian Europe, edited by Peter Goddard, 141-158. Manchester: Manchester University Press, 2013.

Trültzsch, Sasha, and Uwe Breitenborn. "Program Structure Analysis of the GDR Television 1956 to 1991." Siegener Periodicum zur internationalen empirischen Literaturwissenschaft 25 (2006): 16.

Voß, Matthias, and Helmut Matthes. "Die Beziehungen DDR - VR Mosambik zwischen Erwartungen und Wirklichkeit." In Wir haben Spuren hinterlassen!: die DDR in Mosambik: Erlebnisse, Erfahrungen und Erkenntnisse aus drei Jahrzehnten, edited by Matthias Voß, 12-33. Münster: LIT Verlag, 2005.

Vučetić, Radina. "We Shall Win: Yugoslav Film Cooperation with FRELIMO." Revista Crítica de Ciências Sociais (2019): 131-50.

Weis, Toni. “The Politics Machine: On the Concept of 'Solidarity' in East German Support for SWAPO.” Journal of Southern African Studies 37 (2011): 351- 67.

West, Harry G. "Girls with Guns: Narrating the Experience of War of FRELIMO's 'Female Detachment."' In Children and Youth on the Front Line, edited by Jo Boyden and Joanna de Berry, 105-29. New York: Berghahn Books, 2004.

Williams, Raymond. “Distance.” London Review of Books, June 17, 1982.

Winiecki, Jan. Shortcut or Piecemeal: Economic Development Strategies and Structural Change. Budapest: Central European University Press, 2016.

Witkowski, Gregory. "Between Fighters and Beggars: Socialist Philanthropy and the Imagery of Solidarity in East Germany." In Comrades of Color: East Germany in the Cold War World, edited by Quinn Slobodian, 73-95. New York: Berghahn Books, 2015.

Wolle, Stefan. Die heile Welt der Diktatur: Alltag und Herrschaft in der DDR 1971-1989. Berlin: Ch. Links, 2013.

Yaqub, Nadia. Palestinian Cinema in the Days of Revolution. Austin: University of Texas Press, 2018. 